\title{
Opening the Markets for Business Services : Industrial Perspective for Developing Countries
}

\author{
Hildegunn Kyvik Nordås \\ Organisation of Economic Co-operation and Development (OECD)
}

\begin{abstract}
Intra-industry trade is driven by product differentiation and economies of scale. Business services are important for developing and marketing new varieties. Yet, their role for product differentiation has attracted little attention in the literature. This paper contributes to filling this gap by estimating trade costs in business services and exploring the relationships between such costs and the Grubel-Lloyd index of intra-industry trade. High trade costs in business services are associated with a low level of product differentiation in downstream industries, particularly in the motor vehicle industry. Open markets in business services could help industrial upgrading in developing countries.
\end{abstract}

- JEL Classification: F12

- Keywords: Product Differentiation, Services Trade, Trade Costs

\section{Introduction}

The difference between a Versace T-shirt that fetches \$200 and an five dollar H\&M T-shirt largely comes down to design and marketing. While Versace and other luxury fashion brands have tended to source in Italy, France and other developed countries, H\&M mainly source from low-cost countries such as China. The most recent trend, however, is that even luxury brands are shifting to source fashion clothing from lower-cost countries, starting with eastern European countries, but increasingly also North Africa and Asia. A precondition for low-cost

\footnotetext{
*Corresponding address: Organisation of Economic Co-operation and Development (OECD), Trade and Agriculture Directorate. 2 Rue Andre-Pascal, 75775 Paris CEDEX 16, France. Tel: +33 145248890. Mobile: +33 678248493. E-mail: Hildegunn.Nordas@oecd.org. @2011-Center for Economic Integration, Sejong Institution, Sejong University, All Rights Reserved.
} 
countries to enter the high-end market is that designer services and services related to quality control and training of personnel can be easily imported from the sourcing company or its contractual services suppliers.

Staying competitive in the fashion industry and other markets characterized by product differentiation requires continuous innovation based on up-to date knowledge of consumer tastes, trends and needs. Business services play an important role in this regard. A thick market for business services increases flexibility, reduces risk and solves problems related to entering new markets or complying with new regulation in familiar markets. Most manufacturers do not have in-house capacity to deal with non-recurring tasks that are specific to each market, nor would it be economical or practical to acquire such capacity. Multinational companies therefore tend to source business services in the host countries in order to get access to local expertise on culture, legal systems and other relevant features of the business environment, while they also encourage their regular services suppliers to follow them into new markets (Bryson et al., 2004). Trade and investment in business services thus appear to be important elements of internationalization of downstream manufacturing industries.

Popular perceptions are that business services can easily be outsourced following the proliferation of the internet. However, a firm's in-house and externally sourced services are interwoven at all stages of manufacturing production from design, $\mathrm{R} \& \mathrm{D}$, market research and testing at the pre-production stage, through process design, quality control, procurement, maintenance and many more aspects during production, to marketing packaging, and after sales services (Bryson et al., 2004). In many cases frequent face-to-face interactions between internal and external services providers is required. Therefore restrictions on foreign direct investment (FDI) and movement of people are important barriers for local manufacturers' ability to source business services from international markets. If movement of people and commercial presence are complementary to cross-border trade, which is likely, trade costs may be high, even in the absence of policy restrictions on cross-border trade.

This paper contributes to the empirical literature in four areas. First it provides an analysis of the determinants of trade in business services using the gravity model. Second, it uses the gravity model results to estimate relative trade costs in services. Third, it provides a detailed study of patterns of intra-industry trade and changes in these patterns over time in selected manufacturing industries. These three elements provide insights in their own right, and constitute the building 
blocks of the main area of interest; the relationship between access to a diversified supplier base in business services and product differentiation in downstream manufacturing. In order to explore such a relationship, measures of both product differentiation and the thickness of the business services market are needed. A suitable indicator of product differentiation may be found in the Grubel-Lloyd index of intra-industry trade. ${ }^{1}$ As is well-known from trade theory, product differentiation is a source of gains from trade in its own right. Thus, when there are fixed costs related to developing a new variety, the number of varieties is limited by the size of the market, which in turn may be extended through trade (Krugman, 1979). Countries with a high score on the Grubel-Lloyd index are therefore likely to produce and consume more differentiated goods. The proposed indicator of the thickness of the market for business services is trade costs in business services. If trade costs are low, local manufacturers presumably have the opportunity to source services from international markets. The extent to which services are actually sourced internationally, however, depends on the characteristics of the local business services market, and observed trade flows are therefore less suitable as an indicator of market thickness.

Trade negotiators are usually concerned with either securing market access for exporters or protecting jobs in import-competing sectors. The impact of trade costs on downstream firms which use traded inputs, in contrast, is largely ignored. A notable exception is raw materials for which export constraints have become a concern lately. However, this paper argues that access to a diversified supplier base in business services deserves at least as much attention as access to a reliable flow of raw materials, since also business services provide essential inputs to manufacturing.

The rest of the paper is organised as follows. Section two relates the paper to previous research. Section three outlines the analytical framework, while section four presents the data and provides some descriptive statistics. Gravity model based estimates of trade costs in services are presented in section five. These are related to measures of product differentiation in section six. Finally, policy implications are briefly discussed in section seven which concludes.

\section{Relations to Previous Research}

To the best of my knowledge, there are no published studies that analyze the role of business services for product differentiation. The paper that comes closest in

\footnotetext{
${ }^{1}$ See Grubel and Lloyd (1975).
} 
spirit to mine is Francois and Woerz (2008). They find that increased business services openness, as measured by services imports or FDI inflows, has a strong positive effect on exports in downstream manufacturing industries. This paper differs from theirs in several ways. First, I am interested in the role of business services for product differentiation in downstream industries. This is an important question since product differentiation is associated with industrial upgrading which is a central policy objective, particularly in developing countries. Second, I believe that trade costs are a better measure of access to a diversified supplier base in services than is actual trade and FDI in business services. While some countries may have a large and diversified domestic business services supplier base, others may not have such a base or may have requirements that can best be satisfied by foreign suppliers. What is crucial for the purpose of this study is to what extent manufacturers' sourcing of business services is constrained by trade costs.

Although no directly comparable papers have been identified, empirical studies on the relationship between trade in business services and performance in downstream industries provide important insights and inspiration. For instance an in-depth study of Ireland, a leading trader in business services, found that international production networks require a number of supporting supply chain management services. In addition, manufacturing subsidiaries require a number of supporting sales and marketing services both from the home and the host country. Finally, moving up the value chain in manufacturing typically goes together with an embedding of higher services content in the manufactured product (Grimes, 2006). ${ }^{2}$

The study also draws on insights from stylized general equilibrium modelling. Markusen (1999) demonstrated that trade in intermediate inputs generates gains from specialization both due to international division of labour and lower costs of intermediate inputs. Markusen et al., (2005) discussed possible complementarities between foreign expertise and local service providers arguing that foreign experts could open bottlenecks and unleash potential industrial capacity in importing countries. Robert-Nicoud (2008) shows how offshoring of services could help strengthen competitiveness in downstream industries and support agglomeration of manufacturing in rich countries for a wider range of trade costs than what would be the case without offshoring. Nordås (2010) finds that countries with superior supply chain management technology would strengthen their comparative advantage in downstream manufacturing following a reduction in business services trade costs.

${ }^{2}$ Other studies that have found strong interdependence between manufacturing and business services activities are Francois (1990), Diaz Fuentes (1999) and Guerrieri and Meliciani (2005). 


\section{Analytical Framework}

This section sets out the analytical framework for the empirical investigation to follow in sections four and five. As noted the contribution of this paper to the literature is empirical. The models applied should be well known and are therefore not discussed in detail.

\section{A. The gravity model and trade costs}

The gravity model has been widely applied both for explaining trade patterns and for estimating relative trade costs. This paper follows Egger (2008) who specifies the gravity equation as follows:

$$
\begin{aligned}
\ln \left(n_{i t} p_{i t} x_{i j t}\right)= & \beta_{1} \ln \left(D_{i j}\right)+\beta_{2} \ln \left(D_{i j}\right) * \ln \left(n_{i t}\right)+\beta_{3} \ln \left(D_{i j}\right)^{*} \ln \left(p_{i t}\right)+\beta_{4} \ln \left(D_{i j}\right)^{*} \ln \left(n_{j t}\right) \\
& +\beta_{5} \ln \left(D_{i j}\right) * \ln \left(p_{j t}\right)+\gamma_{i t}+\chi_{j t}+\varepsilon_{i j t}
\end{aligned}
$$

The left hand side represents exports from country $i$ to country $j$ at time $t$, which in turn is broken down on export volume per representative firm $\left(x_{i j t}\right)$, the price of the product $\left(p_{i t}\right)$ and the number of varieties $\left(n_{i t}\right)$. The right hand side captures relative trade costs and market size where $D_{i j}$ represents the distance between country $i$ and $j$ whereas $\gamma_{i t}$ and $\chi_{j t}$ represent exporter $\mathrm{x}$ time and importer $\mathrm{x}$ time fixed effects respectively. ${ }^{3}$ The last term is an error term. What distinguishes Egger's specification is the use of interaction terms between distance and the measures of prices and market size. These are based on the observation that the marginal impact of distance depends on price levels and market size of trading partners; a result that is apparent when differentiating the gravity equation. The terms $n_{i t}$ and $\ln p_{i t}$ and the corresponding terms for the importer, are captured by the country $\mathrm{x}$ time fixed effects.

Peter Egger's suggested methodology is applied to trade in business services (Extended Balance of Payments Services (EBOPS) category 268) and computer and information services (EBOPS 262); for comparison the regressions are also run for total services. However, I use GDP as a proxy for market size and the number

${ }^{3}$ I am grateful to an anonymous referee for pointing out how the problem of convergence in Poisson regressions with a large number of dummies can be overcome. See also Santos Silva and Tenreyro (2010). 
of varieties and GDP per capita as a proxy for the price level. ${ }^{4}$

Several estimation techniques have been applied to the gravity equation. Early research used standard ordinary least squares (OLS). However, there are at least two problems with this technique that have been revealed in more recent literature. First, heteroskedasticity is a serious problem; second, a relatively large share of all possible bilateral trade flows is zero. Using OLS on log-linearized data omits the zero trade observations and results in inconsistent parameter estimates due to heteroskedasticity. An alternative technique, pseudo Poisson maximum likelihood (PPML), solves both problems (Santos Silva and Tenreyro, 2006). Both OLS and PPML estimates are made for comparison and robustness checks.

The gravity model can be used for more than simply analysing the relationship between trade costs and trade flows. One can also turn the question around and ask what can be inferred about trade costs from observed trade flows? Several studies have approximated relative trade costs by first estimating the core gravity model including natural barriers to trade only, and next using the resulting parameters to predict trade flows for each country pair and then finally using the difference between predicted and actual trade flows as a proxy for policy-determined trade costs. The methodology for estimating relative trade costs used here is as follows:

$$
t c_{i j t}=\frac{E\left(x_{i j t}\right)}{x_{i j t}} ; \quad t c i n d_{i j t}=\frac{t c_{i j t}-\min t c_{i j t}}{\max t c_{i j t}-\min t c_{i j t}}
$$

$E\left[x_{i j t}\right]$ is defined as predicted bilateral exports. For exposition purposes these ratios are normalized to a scale between zero and unity using min-max. The country pair with the smallest ratio of predicted to actual trade flows is assigned a relative trade cost index of zero, whereas the country pair with the highest ratio is assigned a relative trade cost index of unity.

\section{B. Intra-industry trade}

Intra-industry trade occurs when countries produce different varieties of the same product and exchange varieties, thereby providing consumers or downstream firms with a broader variety of products. The driving forces behind such trade are

\footnotetext{
${ }^{4}$ Egger (2008) approximates the number of varieties by GDP per capita and uses import and export deflators from IMF Financial Statistics as a proxy for prices. However, under the usual Dixit-Stiglitz monopolistic competition assumptions, the number of varieties in a market is determined by the size of the market, and the appropriate proxy should be GDP. Import price deflators do not exist for services, but it is assumed that the price level of services is strongly related to the wage level in the country in question, which in turn is strongly related to GDP per capita, which is therefore the chosen proxy for the price level.
} 
economies of scale in production and consumers' love of variety (Krugman, 1979). With the proliferation of international production networks, vertical intra-industry trade has also expanded among countries at different levels of income that trade parts and components rather than different varieties of final goods or services. Whether intra-industry trade is horizontal or vertical, a range of business services is needed to make such trade economical. For instance combining international supply chains with just-in-time organization of production obviously requires effective and reliable transport and logistics services, but also technical testing, legal advice, ICT support and many other business services.

The most commonly used measure of intra-industry trade is the Grubel-Lloyd index which is calculated as follows:

$$
G L_{i j k t}=1-\frac{\left|x_{i j k t}-m_{i j k t}\right|}{x_{i j k t}+m_{i j k t}}
$$

where $m_{i j k t}$ represents imports in country $i$ from country $j$ of good $k$ at time $t$. In the case of one-way trade in good $k$ between a country pair, the GL index is zero, while if trade in good $k$ is balanced the GL index is unity. The GL index is calculated both for bilateral and total trade at a Harmonized System (HS) 2-digit level. It should be borne in mind that the value of the index strongly depends on the level of aggregation it is calculated on; the higher the level of aggregation the higher the index. A dynamic version of the GL index, coined the marginal intraindustry trade index (MIIT) has been suggested by Marius Brülhart (1994).

$$
\operatorname{MIIT}_{i j k t}=1-\frac{\left|\Delta x_{i j k}-\Delta m_{i j k}\right|}{\left|\Delta x_{i j k}\right|+\left|\Delta m_{i j k}\right|}
$$

$\Delta$ symbolizes the change in exports or imports from period t-1 to period t. The MIIT index thus reflects to what extent new or lost trade is of the inter-industry or the intra-industry type. Like the GL index it varies between 0 and 1. If exports and imports change at the same rate, the index takes the value of unity, reflecting intraindustry trade. If only exports or imports change, the index takes the value of 0 and changes are of the extra-industry type.

The relation between intra-industry trade in downstream industries and trade costs in business services are explored using the following regression equation:

$$
G L_{i j t}=a+\alpha_{1} \ln \mid G D P C a p_{i t}-G P P \text { cap }_{j t} \mid+\alpha_{2} \ln d_{i j}+\alpha_{3} \ln t c_{i j t}+\gamma_{i}+\chi_{j}+\varphi_{t}+\varepsilon_{i j t}
$$


I control for the log of the absolute value of differences in GDP per capita, since the theory predicts that intra-industry trade is more common among countries at a similar level of income. The predicted sign of $\alpha_{1}$ is negative if intra-industry trade is mainly horizontal, but it could be positive if vertical intra-industry trade based on comparative advantage dominates. Distance is likely to be important not only for trade, but also for the extent of bilateral intra-industry trade. This is particularly the case for vertical intra-industry trade since lead time variability increases with distance, and certainty about timely delivery is particularly important in vertical supply chains (Nordås et al., 2006). In order to capture country-specific explanatory variables and time trends, country and year fixed effects are also included in the analysis. The MIIT index is regressed on the same right-hand side variables as the GL index.

\section{Descriptive Statistics}

There is substantial variation in the intensity of externally sourced business services across manufacturing sectors as well as within manufacturing sectors across countries (Nordås, 2010). The largest variation is found for petrochemicals, electrical machinery and communications equipment, while the highest median scores among OECD and selected emerging economies are found in electrical machinery, steel and chemicals. ${ }^{5}$ It is interesting to study industries that represent different features as far as product differentiation is concerned. Among sectors subject to both international fragmentation of the value chain and horizontal product differentiation are textiles and apparel, electronics and motor vehicles (Gereffi, 1999; Hanson et al., 2005). Product differentiation is also important for high-technology sectors such as pharmaceuticals, while e.g. intermediate goods such as plastics are subject to both vertical and horizontal differentiation at different links in the value chain. The following Harmonized System (HS) industries are selected for further analysis: pharmaceuticals (HS 30), plastics and rubber (HS 39), clothing (HS 61 and 62), electrical machinery (HS 85) and motor vehicles (HS 87). Table 1 reports the mean and standard deviation for the GL and the MIIT indices for these six HS categories calculated for 110 countries during the period 2000-2008. The average conceals large variations both within and between sectors.

${ }^{5}$ The analysis is based on the OECD input-output database that covers 42 countries, including the OECD Members and 11 non-OECD countries. 
Table 1. Indicators of intra-industry trade, selected sectors, 2000-2008.

\begin{tabular}{ccccccccccccccc}
\hline $\begin{array}{c}\text { HS } \\
\text { category }\end{array}$ & \multicolumn{2}{c}{30} & \multicolumn{2}{c}{39} & \multicolumn{2}{c}{61} & \multicolumn{2}{c}{62} & \multicolumn{2}{c}{85} & \multicolumn{2}{c}{87} \\
\hline \multicolumn{3}{c}{ Aggr } & Bilat & Aggr & Bilat & Aggr & Bilat & Aggr & Bilat & Aggr & Bilat & Aggr & Bilat \\
Grubel-Lloyd (GL) \\
Mean & 0.31 & 0.09 & 0.43 & 0.16 & 0.36 & 0.13 & 0.36 & 0.13 & 0.41 & 0.16 & 0.31 & 0.12 \\
S. d. & 0.30 & 0.21 & 0.32 & 0.27 & 0.32 & 0.24 & 0.31 & 0.25 & 0.37 & 0.27 & 0.33 & 0.24 \\
Marginal intra-industry (MIIT) & & & & & & & & & \\
Mean & 0.28 & 0.08 & 0.38 & 0.12 & 0.24 & 0.09 & 0.25 & 0.10 & 0.32 & 0.11 & 0.26 & 0.09 \\
S. d. & 0.32 & 0.20 & 0.34 & 0.25 & 0.32 & 0.22 & 0.31 & 0.22 & 0.35 & 0.24 & 0.31 & 0.21 \\
\hline
\end{tabular}

Note: Aggr. denotes intra-industry trade calculated from a country's total exports and imports; Bilat. represents intra-industry trade calculated for each country pair; S.d. signifies standard deviation.

The intra-industry trade index is higher when calculated on a country's trade with the rest of the world than when taking the average of bilateral trade. This is explained by the fact that firms are located at different stages in international supply chains across countries. For instance, country A may import parts and components of electronic machinery (HS 85) from country B whose industry is located upstream in the supply chain. These parts and components are processed into modules in country $\mathrm{A}$ and exported to country $\mathrm{C}$, which hosts firms downstream in the supply chain. This triangle gives country A a high overall GL index in the sector in question, but a low (or even zero) bilateral GL index both with country $\mathrm{B}$ and $\mathrm{C}$.

It is worth noticing that the standard deviation relative to the mean is high in all product categories, suggesting large variation in the extent to which the countries in the sample participate in intra-industry trade. Perhaps surprisingly, the marginal intra-industry index tends to be relatively low, suggesting that sectoral trade deficits or surpluses tend to grow over time and countries are becoming increasingly specialized. ${ }^{6}$ I also find a statistically significant positive correlation between the GL and the MIIT indices, suggesting that changes in trade flows are more likely to be of the intra-industry type the higher the intra-industry index. Thus, these two results combined indicate deepening international specialization both across and within sectors.

As noted there is a large variation in the data and a number of countries have a GL index close to unity when calculated for trade with the rest of the world. In pharmaceuticals (HS 30) five countries, all of them members of the European Union (Austria, Belgium, Hungary, Italy and the Netherlands), had an overall GL

\footnotetext{
${ }^{6}$ The MIIT index is similar for longer time lags, e.g. five years.
} 
index above 0.99 in one or more years between 2000 and 2008. There are also some country pairs with significant trade in pharmaceuticals and close to balanced trade. The US, for instance, has close to balanced trade in this sector with Canada, China, France, Japan and Spain; Spain's trade with Italy, Netherlands, the UK and USA is close to balanced, whereas Germany features a close-to-unity GL index with the UK, Denmark and Norway. The countries in which intra-industry trade accounts for all changes in trade in this sector are Austria, Belgium, Bulgaria, China, Finland, France, Slovenia and Uruguay. At the opposite end of the spectrum, countries that engage in one-way trade are mainly developing countries, many of them in Africa, and most of them are importers in this sector.

In plastics and rubber (HS 39) Austria, Canada, Finland, Hungary, Indonesia, Italy, Malaysia, Peru and Sweden had a GL index above 0.99 in at least one year in the period analysed. Bosnia Herzegovina, Brazil, China, the Czech Republic, Lithuania, Sweden and Turkey observed an MIIT index larger than 0.99. Countries that engage in one-way trade and only import plastics and rubber are mainly small, developing countries, many of them in Africa. Among the countries with the lowest GL index (below 0.01), only Peru is an exporter in this sector.

Clothing (HS 61) shows quite a different trade pattern. The highest GL index is found in the Czech Republic, Belgium, Costa Rica, Singapore, Albania, Botswana, the Slovak Republic and Poland (GL > 0.99). Among these Singapore and the Slovak Republic also had among the highest MIIT indices (above 0.99) together with Malaysia and Switzerland. The lowest intra-industry index is observed in developing countries also in this sector, but several of the one-way traders are exporters. These include Bangladesh, India, Indonesia, Iran, Pakistan and Syria all with a GL index below 0.01 for at least one year in the period analysed. All of these also had a low MIIT index. Since intermediate inputs in this sector are categorized under different HS codes, one-way trade suggests comparative advantage in clothing combined with weak demand for branded goods at home rather than absence of international supply chains.

In electronics (HS 85), the countries with a GL index above 0.99 are China, the Czech Republic, Denmark, France, Hungary, Luxembourg, Mexico, the Netherlands, the Philippines, Switzerland and Thailand. With the exception of Luxembourg these countries also have a high score on the MIIT index, albeit somewhat lower than the GL index (ranking from 0.59 (Thailand) to 0.97 (China)). At the opposite end are developing countries, which are mainly importers with low scores on both GL and MIIT. 
Balanced trade in the motor vehicle industry (HS 87) is less common and only Austria, Belgium, Canada, Hungary and the Philippines experienced a score on the GL index of more than 0.99 in this sector, whereas only Belgium, Spain and Taiwan scored more than 0.99 on the MIIT index. ${ }^{7}$

\section{Determinants of Trade in Business Services - the Role of Market Size and Geography}

The gravity model as presented in equation (1) above is estimated for computer services (EBOPS 262), other business services (EBOPS 268) and total services (EBOPS 200), first using standard OLS estimates and second, using the Poisson pseudo maximum likelihood (PPML) estimator. Table 2, panels A-C, presents the results.

First, notice that the number of observations is more than twice as high for the PPML than for the OLS regressions for computer services, about a quarter higher

Table 2. Gravity regression results.

\begin{tabular}{lrrrr}
\hline & \multicolumn{4}{c}{ Panel A. Computer services } \\
\hline Variable & \multicolumn{1}{c}{ OLS } & \multicolumn{1}{c}{ OLS } & \multicolumn{1}{c}{ PPML } & \multicolumn{1}{c}{ PPML } \\
\hline ln distance & $-3.326^{* * *}$ & $-2.990^{* * *}$ & $-7.086^{* * *}$ & $-6.915^{* * *}$ \\
& $(0.328)$ & $(0.354)$ & $(0.410)$ & $(0.093)$ \\
ln distance x ln GDP $i$ & $0.068^{* * *}$ & $0.043^{* *}$ & $0.114^{* * *}$ & $0.120^{* * *}$ \\
& $(0.013)$ & $(0.014)$ & $(0.016)$ & $(0.002)$ \\
ln distance x ln GDP $j$ & $0.021^{*}$ & $0.069^{* * *}$ & $0.074^{* * *}$ & $0.067^{* * *}$ \\
& $(0.012)$ & $(0.014)$ & $(0.013)$ & $(0.002)$ \\
ln distance x ln GDP per capita $i$ & -0.023 & $-0.073^{* * *}$ & $0.065^{* * *}$ & $0.041^{* * *}$ \\
& $(0.017)$ & $(0.026)$ & $(0.026)$ & $(0.006)$ \\
ln distance x ln GDP per capita $j$ & $0.042^{* * *}$ & $0.024^{* * *}$ & $0.054^{* * *}$ & $0.066^{* * *}$ \\
& $(0.016)$ & $(0.002)$ & $(0.020)$ & $(0.006)$ \\
Contiguous & $0.351^{* * *}$ & $0.368^{* * *}$ & $0.818^{* * *}$ & $0.822^{* * *}$ \\
& $(0.064)$ & $(0.072)$ & $(0.089)$ & $(0.013)$ \\
Common language & $0.362^{* * *}$ & $0.762^{* * *}$ & $-0.440^{* * *}$ & $-0.416^{* * *}$ \\
& $(0.056)$ & $(0.075)$ & $(0.100)$ & $(0.010)$ \\
\hline N & 4781 & 4781 & 14377 & 11203 \\
Adjusted R ${ }^{2}$ & 0.687 & 0.579 & 0.910 & 0.922 \\
Coutry fixed effects & Yes & No & Yes & No \\
Year fixed effects & Yes & No & Yes & No \\
Coutry x year fixed effects & No & Yes & No & Yes \\
\hline
\end{tabular}

${ }^{7}$ The calculated GL and MIIT indices are available from the author upon request. 
Table 2. Gravity regression results.

\begin{tabular}{|c|c|c|c|c|}
\hline & \multicolumn{4}{|c|}{ Panel B. other business services } \\
\hline Variable & OLS & OLS & PPML & PPML \\
\hline ln distance & $\begin{array}{r}-4.034 * * * \\
(0.213)\end{array}$ & $\begin{array}{r}-7.749 * * * \\
(0.286)\end{array}$ & $\begin{array}{r}-7.070 * * * \\
(0.254)\end{array}$ & $\begin{array}{r}-8.625 * * * \\
(0.027)\end{array}$ \\
\hline $\ln$ distance $\mathrm{x} \ln$ GDP $i$ & $\begin{array}{r}0.019 * * * \\
(0.008)\end{array}$ & $\begin{array}{r}0.067^{* * *} \\
(0.010)\end{array}$ & $\begin{array}{r}0.080^{* * * *} \\
(0.009)\end{array}$ & $\begin{array}{r}0.101^{* * *} \\
(0.001)\end{array}$ \\
\hline $\ln$ distance $\mathrm{x} \ln \mathrm{GDP} j$ & $\begin{array}{r}0.072 * * * \\
(0.008)\end{array}$ & $\begin{array}{r}0.085^{* * *} \\
(0.010)\end{array}$ & $\begin{array}{r}0.151^{* * *} \\
(0.009)\end{array}$ & $\begin{array}{r}0.153 * * * \\
(0.001)\end{array}$ \\
\hline ln distance $\mathrm{x} \ln$ GDP per capita $i$ & $\begin{array}{r}0.050 * * * \\
(0.010)\end{array}$ & $\begin{array}{r}0.134 * * * \\
(0.015)\end{array}$ & $\begin{array}{r}0.044 * * * \\
(0.015)\end{array}$ & $\begin{array}{r}0.138^{* * * *} \\
(0.001)\end{array}$ \\
\hline ln distance $\mathrm{x} \ln$ GDP per capita $j$ & $\begin{array}{r}0.014 \\
(0.010)\end{array}$ & $\begin{array}{r}0.127 * * * \\
(0.015)\end{array}$ & $\begin{array}{r}-0.034 * * * \\
(0.014)\end{array}$ & $\begin{array}{r}-0.035^{* * *} * \\
(0.001)\end{array}$ \\
\hline Contiguous & $\begin{array}{r}0.440 * * * \\
(0.048)\end{array}$ & $\begin{array}{r}0.316^{* * *} \\
(0.061)\end{array}$ & $\begin{array}{r}0.652 * * * \\
(0.065)\end{array}$ & $\begin{array}{r}0.652^{* * * *} \\
(0.004)\end{array}$ \\
\hline Common language & $\begin{array}{r}0.414 * * * \\
(0.042)\end{array}$ & $\begin{array}{r}0.514 * * * \\
(0.053)\end{array}$ & $\begin{array}{r}0.205^{* *} \\
(0.058)\end{array}$ & $\begin{array}{r}0.248^{* *} \\
(0.003)\end{array}$ \\
\hline $\mathrm{N}$ & 10422 & 14960 & 17735 & 13577 \\
\hline Adjusted $\mathrm{R}^{2}$ & 0.779 & 0.832 & 0.931 & 0.938 \\
\hline Coutry fixed effects & Yes & No & Yes & No \\
\hline Year fixed effects & Yes & No & Yes & No \\
\hline Coutry x year fixed effects & No & Yes & No & Yes \\
\hline & \multicolumn{4}{|c|}{ Panel C. Total services } \\
\hline Variable & OLS & OLS & PPML & PPML \\
\hline In distance & $\begin{array}{r}-4.567 * * * \\
(0.129)\end{array}$ & $\begin{array}{r}-5.849 * * * \\
(0.128)\end{array}$ & $\begin{array}{r}-4.678^{* * * *} \\
(0.161)\end{array}$ & $\begin{array}{r}-6.186^{* * * *} \\
(0.008)\end{array}$ \\
\hline ln distance $\mathrm{x} \ln$ GDP $i$ & $\begin{array}{r}0.034 * * * \\
(0.005)\end{array}$ & $\begin{array}{r}0.045^{* *} \\
(0.005)\end{array}$ & $\begin{array}{r}0.053 * * * \\
(0.005)\end{array}$ & $\begin{array}{r}0.062 * * * \\
(0.000)\end{array}$ \\
\hline ln distance $\mathrm{x} \ln \mathrm{GDP} j$ & $\begin{array}{r}0.059 * * * \\
(0.005)\end{array}$ & $\begin{array}{r}0.086^{* * *} \\
(0.001)\end{array}$ & $\begin{array}{r}0.039 * * * \\
(0.006)\end{array}$ & $\begin{array}{r}0.048^{* * *} * \\
(0.000)\end{array}$ \\
\hline ln distance $\mathrm{x} \ln$ GDP per capita $i$ & $\begin{array}{r}0.059 * * * \\
(0.006)\end{array}$ & $\begin{array}{r}0.148^{* * *} \\
(0.009)\end{array}$ & $\begin{array}{r}0.063 * * * \\
(0.008)\end{array}$ & $\begin{array}{r}0.122 * * * \\
(0.000)\end{array}$ \\
\hline ln distance $\mathrm{x} \ln$ GDP per capita $j$ & $\begin{array}{r}0.053 * * * \\
(0.006)\end{array}$ & $\begin{array}{r}0.032 * * * \\
(0.001)\end{array}$ & $\begin{array}{r}0.090 * * * \\
(0.009)\end{array}$ & $\begin{array}{r}0.130 * * * \\
(0.000)\end{array}$ \\
\hline Contiguous & $\begin{array}{r}0.692 * * * \\
(0.033)\end{array}$ & $\begin{array}{r}0.880^{* * *} \\
(0.037)\end{array}$ & $\begin{array}{r}0.319 * * * \\
(0.038)\end{array}$ & $\begin{array}{r}0.343^{* * *} * \\
(0.001)\end{array}$ \\
\hline Common language & $\begin{array}{r}0.781 * * * \\
(0.025)\end{array}$ & $\begin{array}{r}1.158^{* * *} \\
(0.025)\end{array}$ & $\begin{array}{r}0.401 * * * \\
(0.032)\end{array}$ & $\begin{array}{r}0.406^{* * *} \\
(0.001)\end{array}$ \\
\hline $\mathrm{N}$ & 30247 & 30247 & 41976 & 35644 \\
\hline Adjusted $\mathrm{R}^{2}$ & 0.811 & 0.754 & 0.929 & 0.930 \\
\hline Coutry fixed effects & Yes & No & Yes & No \\
\hline Year fixed effects & Yes & No & Yes & No \\
\hline Coutry $\mathrm{x}$ year fixed effects & No & Yes & No & Yes \\
\hline
\end{tabular}

Note: Standard errors in parentheses. ${ }^{* * *}, * *$, and $*$ represent significance levels of 1,5 and $10 \%$ respectively. 
for other business services and about a fifth higher for total services. This reflects the fact that a significant number of all possible bilateral trade flows are zero, with the highest number in computer services. ${ }^{8}$

Contrary to popular perceptions, distance is highly relevant for cross-border trade both for computer services and other business services. The OLS and PPML regressions give similar parameter estimates as far as sign and statistical significance are concerned, whereas the PPML regressions appear to give the best fit. The two PPML regressions, one with country and time fixed effects and the other with the full set of time $\mathrm{x}$ country dummies yield similar overall fit and predictions. ${ }^{9}$ In order to make the latter regressions converge, a significant number of observations had to be dropped, and a large number of dummies were statistically insignificant. I therefore use the PPML regressions with country and year fixed effects for further analysis.

The regression results suggest that the marginal impact of distance is smaller for large countries and countries with high income per capita. The disadvantage of remoteness is in other words larger the smaller and poorer the country. For total services, countries with a common border tend to trade about a third more with each other than countries without a common border. For computer services and other business services, however, contiguous countries tend to trade around twice as much with each other, all else equal. Countries that share a common official language tend to trade about $50 \%$ more services overall with each other and a quarter more in other business services, while for computer services the sign of the parameter on common language is negative in the PPML regressions.

The regression results presented in Table 2, third column, are used for estimating bilateral services trade costs for each sector and for total services trade as indicated by equation (2) above. The min-max normalisation returns values between zero and unity. The mean is 0.12 for total services, 0.11 for computer services and 0.10 for other business services, suggesting that the distribution is skewed towards the left and the medians smaller than the means (the median is about 0.06 for all sectors). The average estimated trade cost index across partner countries for a selection of countries is presented in Figure 1.

\footnotetext{
${ }^{8}$ It is, however, possible that data coverage varies between sectors as well.

${ }^{9}$ Notice that the main difference between the regressions using country and time fixed effects and those using the full set of country $\mathrm{x}$ time dummies is the relative importance of the direct impact of distance and the interaction between distance and GDP and GDP per capita.
} 
Figure 1. Estimated trade costs index, 2005.

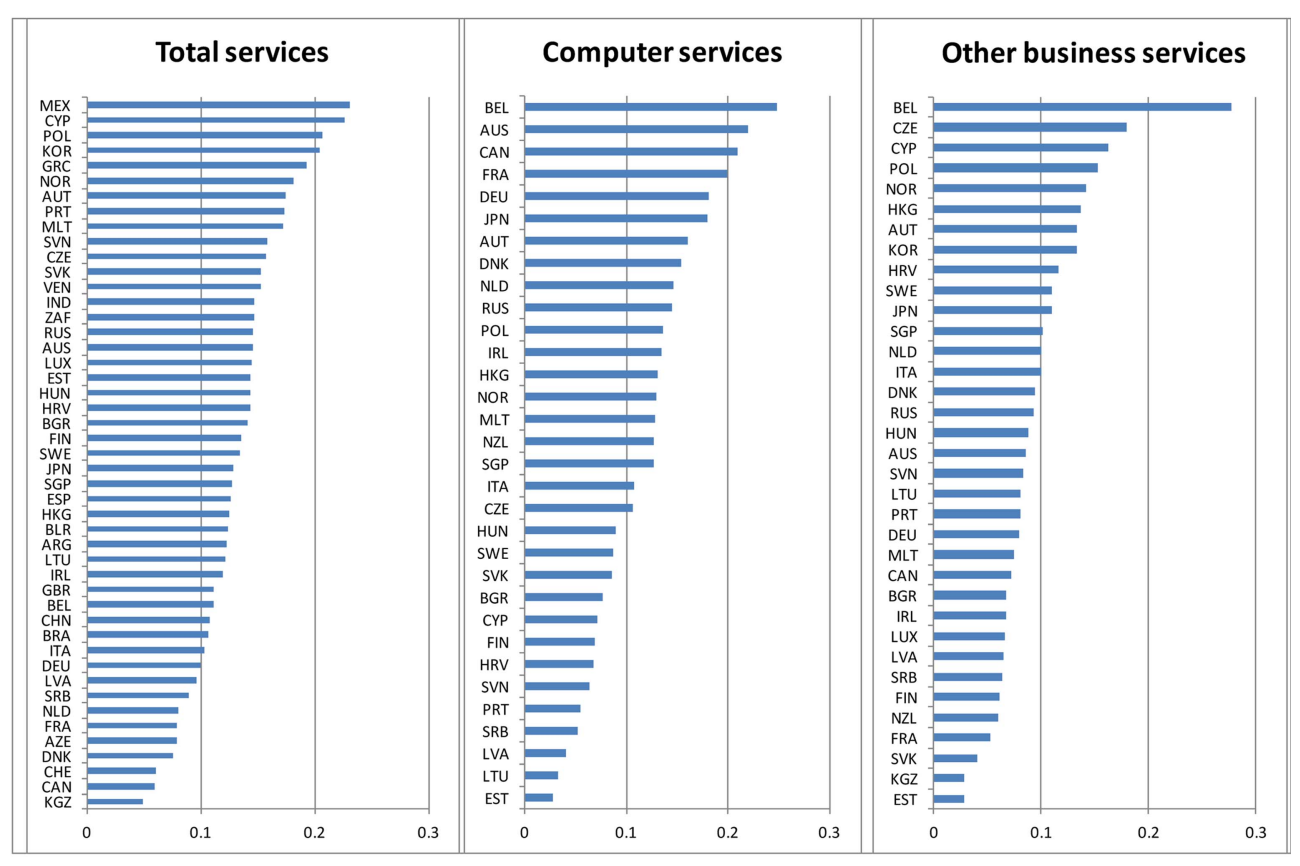

Note: The figure shows the average estimated trade cost index over all trading partners based on estimated bilateral trade costs using the PPML estimator on equation (2) with country and year fixed effects.

Since the estimated costs are normalized, the absolute levels of trade costs are not comparable across sectors. The country that has the lowest estimated total services trade costs is somewhat surprisingly, Kyrgyzstan. The other countries with low services trade costs are less surprising, including Canada, Switzerland, Denmark and - another surprise - Azerbaijan. At the other end of the spectrum are Mexico, Cyprus, Poland, Korea and Greece. Recall that the trade costs index captures policy-induced relative trade costs, having controlled for natural trade barriers. Low estimated trade costs in the two former Soviet Republics could therefore be due to close to prohibitive natural barriers to trade with a significant number of trading partners such that the relative importance of policy-induced barriers is low.

The three Baltic countries have the lowest estimated trade costs in computer services followed by other Eastern and Central European countries. In a number of studies the Baltic region is found to be quite liberal as far as services trade regulation is concerned and the results should not be surprising. In the next exercise these estimated trade costs are used for analysing the relation between 
services trade costs and performance in down-stream industries.

\section{Trade Costs in Business Services and Performance in Downstream Industries}

\section{A. Cross-border services trade costs and intra-industry trade in manu- facturing}

The estimated services trade costs summarized in Figure 1 are next plugged into equation (5), relating them to product differentiation as measured by the Grubel-

Table 3. Services trade costs and intra-industry trade.

GLM regressions with country and year fixed effects.

\begin{tabular}{|c|c|c|c|c|c|c|}
\hline \multicolumn{7}{|c|}{ Panel A. Pharmaceuticals (HS 30) } \\
\hline & \multicolumn{3}{|c|}{ Grubel Lloyd index } & \multicolumn{3}{|c|}{ Marginal intra-industry trade index } \\
\hline & $\begin{array}{c}\text { Total } \\
\text { services }\end{array}$ & $\begin{array}{c}\text { Computer } \\
\text { services }\end{array}$ & $\begin{array}{l}\text { Other busi- } \\
\text { ness services }\end{array}$ & $\begin{array}{c}\text { Total } \\
\text { services }\end{array}$ & $\begin{array}{c}\text { Computer } \\
\text { services }\end{array}$ & $\begin{array}{c}\text { Other busi- } \\
\text { ness services }\end{array}$ \\
\hline In distance & $\begin{array}{r}-0.681^{* * *} \\
(0.019)\end{array}$ & $\begin{array}{r}-0.559^{* * *} \\
(0.028)\end{array}$ & $\begin{array}{r}-0.548^{* * *} \\
(0.027)\end{array}$ & $\begin{array}{r}-0.447 * * * \\
(0.022)\end{array}$ & $\begin{array}{r}-0.417 * * * \\
(0.035)\end{array}$ & $\begin{array}{r}-0.380^{* * *} \\
(0.032)\end{array}$ \\
\hline $\begin{array}{l}\text { In difference } \\
\text { GDP per capita }\end{array}$ & $\begin{array}{r}-0.282 * * * \\
(0.013)\end{array}$ & $\begin{array}{r}-0.271 * * * \\
(0.019)\end{array}$ & $\begin{array}{r}-0.265^{* * *} \\
(0.018)\end{array}$ & $\begin{array}{r}-0.141 * * * \\
(0.015)\end{array}$ & $\begin{array}{r}-0.143 * * * \\
(0.023)\end{array}$ & $\begin{array}{r}-0.152 * * * \\
(0.021)\end{array}$ \\
\hline $\begin{array}{l}\text { Ln trade costs } \\
\text { services }\end{array}$ & $\begin{array}{r}-0.027 * * * \\
(0.010)\end{array}$ & $\begin{array}{r}-0.029 * * * \\
(0.007)\end{array}$ & $\begin{array}{r}-0.021 * * * \\
(0.009)\end{array}$ & $\begin{array}{r}-0.060 * * * \\
(0.013)\end{array}$ & $\begin{array}{l}-0.012 \\
(0.009)\end{array}$ & $\begin{array}{r}-0.029 * * * \\
(0.011)\end{array}$ \\
\hline $\mathrm{N}$ & 27658 & 9721 & 11549 & 24997 & 8492 & 10163 \\
\hline AIC & 0.561 & 0.691 & 0.687 & 0.1542 & 0.653 & 0.653 \\
\hline $\mathrm{BIC}$ & -272612 & -84755 & -102582 & -242267 & -72188 & -88125 \\
\hline
\end{tabular}

Panel B. Plastics and rubber (HS 39)

\begin{tabular}{|c|c|c|c|c|c|c|}
\hline & \multicolumn{3}{|c|}{ Grubel Lloyd index } & \multicolumn{3}{|c|}{ Marginal intra industry trade index } \\
\hline & $\begin{array}{c}\text { Total } \\
\text { services }\end{array}$ & $\begin{array}{l}\text { Computer } \\
\text { services }\end{array}$ & $\begin{array}{l}\text { Other busi- } \\
\text { ness services }\end{array}$ & $\begin{array}{c}\text { Total } \\
\text { services }\end{array}$ & $\begin{array}{l}\text { Computer } \\
\text { services }\end{array}$ & $\begin{array}{l}\text { Other busi- } \\
\text { ness services }\end{array}$ \\
\hline ln distance & $\begin{array}{r}-0.462^{* * * *} \\
(0.015)\end{array}$ & $\begin{array}{r}-0.459 * * * \\
(0.023)\end{array}$ & $\begin{array}{r}-0.450^{* * * *} \\
(0.021)\end{array}$ & $\begin{array}{r}-0.378^{* * * *} \\
(0.018)\end{array}$ & $\begin{array}{r}-0.331^{* * * *} \\
(0.031)\end{array}$ & $\begin{array}{r}-0.287^{* * * *} \\
(0.028)\end{array}$ \\
\hline $\begin{array}{l}\text { In difference } \\
\text { GDP per capita }\end{array}$ & $\begin{array}{r}-0.112 * * * \\
(0.009)\end{array}$ & $\begin{array}{r}-0.042 * * * \\
(0.013)\end{array}$ & $\begin{array}{r}-0.077 * * * \\
(0.012)\end{array}$ & $\begin{array}{r}-0.045^{* * * *} \\
(0.011)\end{array}$ & $\begin{array}{r}-0.000 \\
(0.000)\end{array}$ & $\begin{array}{r}-0.032 * * \\
(0.016)\end{array}$ \\
\hline $\begin{array}{l}\text { Ln trade costs } \\
\text { services }\end{array}$ & $\begin{array}{r}-0.068^{* * * *} \\
(0.006)\end{array}$ & $\begin{array}{r}-0.015^{* * *} * \\
(0.005)\end{array}$ & $\begin{array}{r}-0.032 * * * \\
(0.006)\end{array}$ & $\begin{array}{r}-0.062 * * * \\
(0.008)\end{array}$ & $\begin{array}{r}-0.002 \\
(0.007)\end{array}$ & $\begin{array}{r}-0.027 * * * \\
(0.008)\end{array}$ \\
\hline $\mathrm{N}$ & 30041 & 10435 & 12390 & 27405 & 9241 & 11057 \\
\hline AIC & 0.773 & 0.903 & 0.911 & 0.744 & 0.868 & 0.874 \\
\hline BIC & -297150 & -91342 & -110406 & -266362 & -78321 & -95529 \\
\hline
\end{tabular}


Table 3. Services trade costs and intra-industry trade.

\begin{tabular}{|c|c|c|c|c|c|c|}
\hline \multicolumn{7}{|c|}{ Panel C. Articles of apparel and clothing accessories, knitted or crocheted (HS 61) } \\
\hline & \multicolumn{3}{|c|}{ Grubel Lloyd index } & \multicolumn{3}{|c|}{ Marginal intra industry trade index } \\
\hline & $\begin{array}{c}\text { Total } \\
\text { services }\end{array}$ & $\begin{array}{l}\text { Computer } \\
\text { services }\end{array}$ & $\begin{array}{c}\text { Other busi- } \\
\text { ness services }\end{array}$ & $\begin{array}{c}\text { Total } \\
\text { services }\end{array}$ & $\begin{array}{c}\text { Computer } \\
\text { services }\end{array}$ & $\begin{array}{c}\text { Other busi- } \\
\text { ness services }\end{array}$ \\
\hline ln distance & $\begin{array}{r}-0.563 * * * \\
(0.016)\end{array}$ & $\begin{array}{r}-0.648^{* * * *} \\
(0.029)\end{array}$ & $\begin{array}{r}-0.537 * * * \\
\quad(0.026)\end{array}$ & $\begin{array}{r}-0.422 * * * \\
(0.022)\end{array}$ & $\begin{array}{r}-0.382 * * * \\
(0.036)\end{array}$ & $\begin{array}{r}-0.350 * * * \\
(0.033)\end{array}$ \\
\hline $\begin{array}{l}\text { In difference } \\
\text { GDP per capita }\end{array}$ & $\begin{array}{r}0.020^{* *} \\
(0.010)\end{array}$ & $\begin{array}{l}0.031^{*} \\
(0.016)\end{array}$ & $\begin{array}{r}0.012 \\
(0.016)\end{array}$ & $\begin{array}{r}0.021 \\
(0.014)\end{array}$ & $\begin{array}{r}0.062 * * * \\
(0.025)\end{array}$ & $\begin{array}{r}0.005 \\
(0.021)\end{array}$ \\
\hline $\begin{array}{l}\text { Ln trade costs } \\
\text { services }\end{array}$ & $\begin{array}{r}-0.097 * * * \\
(0.007)\end{array}$ & $\begin{array}{r}-0.000 \\
(0.007)\end{array}$ & $\begin{array}{rr}0 & -0.070 * * * \\
) & (0.009)\end{array}$ & $\begin{array}{r}-0.067 * * * \\
(0.010)\end{array}$ & $\begin{array}{r}-0.007 \\
(0.009)\end{array}$ & $\begin{array}{r}-0.046 * * * \\
(0.011)\end{array}$ \\
\hline $\mathrm{N}$ & 27817 & 10065 & 11899 & 24697 & 8785 & 10461 \\
\hline $\mathrm{AIC}$ & 0.706 & 0.742 & 0.7 & 0.642 & 0.660 & 0.668 \\
\hline $\mathrm{BIC}$ & -272436 & -87871 & -105736 & -237213 & -74840 & -90779 \\
\hline
\end{tabular}

Panel D. Articles of apparel and clothing accessories, not knitted or crocheted (HS 62)

\begin{tabular}{crrrrrr}
\hline & \multicolumn{3}{c}{ Grubel Lloyd index } & \multicolumn{2}{c}{ Marginal intra industry trade index } \\
\hline & \multicolumn{1}{c}{ Total } & \multicolumn{2}{c}{ Computer } & Other busi- & \multicolumn{1}{c}{ Total } & \multicolumn{2}{c}{ Computer } & Other busi- \\
& \multicolumn{1}{c}{ services } & \multicolumn{1}{c}{ services } & ness services & \multicolumn{1}{c}{ services } & \multicolumn{1}{c}{ services } & ness services \\
\hline In distance & $-0.520^{* * *}$ & $-0.584^{* * *}$ & $-0.532^{* * *}$ & $-0.379^{* * *}$ & $-0.352^{* * *}$ & $-0.339^{* * *}$ \\
& $(0.016)$ & $(0.028)$ & $(0.025)$ & $(0.021)$ & $(0.036)$ & $(0.032)$ \\
ln difference & $-0.033^{* * *}$ & 0.019 & $-0.047^{* * *}$ & -0.003 & $0.053^{* *}$ & -0.001 \\
GDP per capita & $(0.010)$ & $(0.016)$ & $(0.015)$ & $(0.013)$ & $(0.023)$ & $(0.020)$ \\
Ln trade costs & $-0.089^{* * *}$ & -0.006 & $-0.070^{* * *}$ & $-0.051^{* * *}$ & $-0.017 *$ & $-0.063 * * *$ \\
services & $(0.007)$ & $(0.007)$ & $(0.008)$ & $(0.009)$ & $(0.009)$ & $(0.011)$ \\
\hline $\mathrm{N}$ & 28109 & 10071 & 11949 & 25089 & 8784 & 10515 \\
AIC & 0.733 & 0.756 & 0.766 & 0.653 & 0.681 & 0.678 \\
BIC & -275288 & -87910 & -106162 & -241339 & -74767 & -91317 \\
\hline
\end{tabular}

Panel E. Electrical machinery and parts thereof (HS 85)

\begin{tabular}{|c|c|c|c|c|c|c|}
\hline & \multicolumn{3}{|c|}{ Grubel Lloyd index } & \multicolumn{3}{|c|}{ Marginal intra industry trade index } \\
\hline & $\begin{array}{c}\text { Total } \\
\text { services }\end{array}$ & $\begin{array}{l}\text { Computer } \\
\text { services }\end{array}$ & $\begin{array}{l}\text { Other busi- } \\
\text { ness services }\end{array}$ & $\begin{array}{c}\text { Total } \\
\text { services }\end{array}$ & $\begin{array}{c}\text { Computer } \\
\text { services }\end{array}$ & $\begin{array}{l}\text { Other busi- } \\
\text { ness services }\end{array}$ \\
\hline ln distance & $\begin{array}{r}-0.428^{* * *} \\
(0.014)\end{array}$ & $\begin{array}{r}-0.385^{* * *} \\
(0.022)\end{array}$ & $\begin{array}{r}-0.435^{* * *} \\
(0.020)\end{array}$ & $\begin{array}{r}-0.337 * * * \\
(0.018)\end{array}$ & $\begin{array}{r}-0.362 * * * \\
(0.030)\end{array}$ & $\begin{array}{r}-0.393 * * * \\
(0.028)\end{array}$ \\
\hline $\begin{array}{l}\text { ln difference } \\
\text { GDP per capita }\end{array}$ & $\begin{array}{r}-0.098^{* * *} \\
(0.009)\end{array}$ & $\begin{array}{r}-0.013 \\
(0.013)\end{array}$ & $\begin{array}{r}-0.048^{* * *} * \\
(0.012)\end{array}$ & $\begin{array}{r}-0.017 \\
(0.012)\end{array}$ & $\begin{array}{r}0.020 \\
(0.019)\end{array}$ & $\begin{array}{r}0.002 \\
(0.018)\end{array}$ \\
\hline $\begin{array}{l}\text { Ln trade costs } \\
\text { services }\end{array}$ & $\begin{array}{r}-0.036^{* * *} \\
(0.005)\end{array}$ & $\begin{array}{r}-0.015^{* *} \\
(0.005)\end{array}$ & $\begin{array}{r}-0.020 * * * \\
(0.006)\end{array}$ & $\begin{array}{r}-0.052^{* * *} \\
(0.007)\end{array}$ & $\begin{array}{r}-0.002 \\
(0.008)\end{array}$ & $\begin{array}{r}-0.032 * * * \\
(0.009)\end{array}$ \\
\hline $\mathrm{N}$ & 31262 & 10622 & 12587 & 28867 & 9479 & 11303 \\
\hline $\begin{array}{l}\text { AIC } \\
\text { BIC }\end{array}$ & $\begin{array}{r}0.755 \\
-311274\end{array}$ & $\begin{array}{r}0.875 \\
-93590\end{array}$ & $\begin{array}{r}0.872 \\
-112892\end{array}$ & $\begin{array}{r}0.713 \\
-281414\end{array}$ & $\begin{array}{r}0.824 \\
-80822\end{array}$ & $\begin{array}{r}0.818 \\
-98242\end{array}$ \\
\hline
\end{tabular}


Table 3. Services trade costs and intra-industry trade.

\begin{tabular}{|c|c|c|c|c|c|c|}
\hline & \multicolumn{6}{|c|}{$\begin{array}{l}\text { Panel F. Vehicles other than railway or tramway rolling-stock, } \\
\text { and parts and accessories thereof (HS 87) }\end{array}$} \\
\hline & \multicolumn{3}{|c|}{ Grubel Lloyd index } & \multicolumn{3}{|c|}{ Marginal intra industry trade index } \\
\hline & $\begin{array}{c}\text { Total } \\
\text { services }\end{array}$ & $\begin{array}{l}\text { Computer } \\
\text { services }\end{array}$ & $\begin{array}{l}\text { Other busi- } \\
\text { ness services }\end{array}$ & $\begin{array}{c}\text { Total } \\
\text { services }\end{array}$ & $\begin{array}{l}\text { Computer } \\
\text { services }\end{array}$ & $\begin{array}{l}\text { Other busi- } \\
\text { ness services }\end{array}$ \\
\hline In distance & $\begin{array}{r}-0.399 * * * \\
(0.016)\end{array}$ & $\begin{array}{r}-0.421 * * * \\
(0.024)\end{array}$ & $\begin{array}{r}-0.404^{* * *} \\
(0.021)\end{array}$ & $\begin{array}{r}-0.322 * * * \\
(0.021)\end{array}$ & $\begin{array}{r}-0.364 * * * \\
(0.035)\end{array}$ & $\begin{array}{r}-0.329^{* * *} \\
(0.031)\end{array}$ \\
\hline $\begin{array}{l}\text { ln difference } \\
\text { GDP per capita }\end{array}$ & $\begin{array}{r}-0.043 * * * \\
(0.010)\end{array}$ & $\begin{array}{r}0.024 \\
(0.015)\end{array}$ & $\begin{array}{r}-0.031^{* *} \\
(0.013)\end{array}$ & $\begin{array}{r}-0.006 \\
(0.014)\end{array}$ & $\begin{array}{r}0.063 * * * \\
(0.023)\end{array}$ & $\begin{array}{r}0.022 \\
(0.020)\end{array}$ \\
\hline $\begin{array}{l}\text { Ln trade costs } \\
\text { services }\end{array}$ & $\begin{array}{r}-0.107 * * * \\
(0.008)\end{array}$ & $\begin{array}{r}-0.029 * * * \\
(0.006)\end{array}$ & $\begin{array}{r}-0.060^{* * *} \\
(0.007)\end{array}$ & $\begin{array}{r}-0.111 * * * \\
(0.011)\end{array}$ & $\begin{array}{r}-0.019^{* *} \\
(0.009)\end{array}$ & $\begin{array}{r}-0.036^{* * * *} \\
(0.010)\end{array}$ \\
\hline $\mathrm{N}$ & 28867 & 10077 & 11965 & 26134 & 8846 & 10594 \\
\hline AIC & 0.680 & 0.791 & 0.807 & 0.614 & 0.700 & 0.708 \\
\hline $\mathrm{BIC}$ & -284673 & -87960 & -106295 & -253486 & -75378 & -91981 \\
\hline
\end{tabular}

Note: The GLM uses maximum likelihood optimization and the binominal family. Robust standard errors are in parenthesis. ${ }^{*}, * *$, and $* * *$ signify statistical significance at a 10,5 and $1 \%$ level respectively. The first column under each set of regressions contains the estimated bilateral trade costs for total services, while the second and third columns contain the estimated bilateral trade costs of computer services and other business services respectively. AIC (Akaike Information Criterion) and BIC (Bayesian Information Criterion) report the goodness of fit.

Lloyd index of intra-industry trade. ${ }^{10}$ The Grubel-Lloyd index falls between zero and unity (end points included). An estimation technique that ensures that predicted values also fall between zero and one is the generalized linear model (GLM) with a logit link, which is therefore applied here. ${ }^{11}$ The results are reported in Table 3, Panels A to F, for the six HS categories.

Starting with the GL index regressions, distance has the expected negative sign and is significant at a $1 \%$ level in all regressions. The coefficient on the absolute value of the difference in GDP per capita is also negative in all but one of the regressions (clothing, HS 61) where it is statistically significant at least at a $10 \%$ level. The economic importance of distance for the GL index is somewhat higher for pharmaceuticals and clothing (HS 61), while for the other sectors the coefficient with respect to distance hovers around 0.4. Differences in GDP per capita matter the most in pharmaceuticals, as one would expect. Given the R\&D-intensity of the

\footnotetext{
${ }^{10}$ Since trade costs in services are a generated regressor, the covariance matrix should be adjusted. However, with the large sample used, we believe that this should not affect the results in any significant way.

${ }^{11}$ This GLM methodology for fractional response variables was first proposed by Papke and Wooldridge (1996). For robustness checks the regressions were also run using a probit link, and using glogit instead of GLM. The results were robust to these changes.
} 
sector, Ricardian comparative advantage as well as relative endowments of skilled labor is likely to drive trade in the sector, leaving the GL index relatively low, but with the possibility of specialization on generics in countries with a lower GDP per capita. The economic and statistical significance of GDP per capita is smallest in the textiles industries. This is a sector where countries such as France and Italy specialize in up-market fashion clothing and Bangladesh, China and India in massmarket relatively cheap clothing, and there is some demand for both up-market and mass market clothing in most countries.

Turning to the variable of interest, services trade costs, the coefficient is always negative in the regressions and for total services and business services it is also always statistically significant at a $1 \%$ level. For computer services the estimates are less precise, possibly because of weaker trade data for this sector. ${ }^{12}$ The relation between services trade costs and intra-industry trade varies substantially between sectors. The economic significance is greatest in the motor vehicle and textile sectors. The predicted mean GL index would increase from about 0.19 to about 0.22 both in the motor vehicle and the clothing industry (HS 61) if services trade costs came down from the $75^{\text {th }}$ to the $25^{\text {th }}$ percentile. Textiles and motor vehicles, in addition to electronics are the sectors in which vertical fragmentation have been found to be the most important (Gereffi, 1999; Ando, 2006). Vertical fragmentation requires synchronization of production, which in turn requires effective and reliable communications, logistics and a number of business services such as technical testing, packaging and marketing. The cost, quality and product variety of business services are therefore expected to have the most significant impact in these sectors. The relatively low coefficients on services trade costs in the regressions for the electronics sector are therefore somewhat surprising. ${ }^{13}$ A possible explanation is that electronics production is largely located in Asia in designated industrial or free trade zones where the services supplier base is substantially better than the national average. Furthermore, air transport probably plays a very important role for this sector, a possibility that could not be tested due to lack of data for air transport.

A similar pattern occurs for the relationship between services trade costs and the marginal intra-industry trade index, the MIIT. In this case lower business services

\footnotetext{
${ }^{12}$ Recall from Table 2 that the number of bilateral zero trade flows is much higher in this sector than for business services. There is therefore a risk that the difficulty of distinguishing between absence of trade and absence of data is more severe in this sector.

${ }^{13}$ The possibility that trade costs can have a non-linear impact on the GL index was explored by introducing thresholds. Weak support was found for this assumption, but the overall fit of the regressions did not improve by introducing such thresholds.
} 
trade costs are related to increased product differentiation over time. Overall services trade costs and business services trade costs are statistically significant at a $1 \%$ level in all regressions, while computer services trade costs are significant only in the electronics and motor vehicle industry regressions. Again the effect is strongest in the motor vehicle industry. The predicted mean MIIT at the $75^{\text {th }}$ percentile for overall trade cost is 0.11 as compared to 0.14 at the $25^{\text {th }}$ percentile. In clothing (HS 61) the predicted mean MIIT increases from 0.12 at the $75^{\text {th }}$ percentile overall trade cost to 0.14 at the $25^{\text {th }}$ percentile. Recall from the previous section that the GL and the MIIT indices are positively correlated, suggesting that product differentiation may gather momentum over time and that access to diversified business services at reasonable costs plays an important role in moving up the value chain.

\section{B. Barriers to FDI in services and intra-industry trade in manufacturing}

Business services are certainly traded cross-border, but commercial presence is thought to be a more important mode of supplying services. Furthermore, there is some evidence that cross border trade and foreign direct investment are complementary in many services sectors, including business services (Kox and Nordås, 2009). I therefore also run the regression of GL and MIIT as depicted by equation (5) replacing trade costs with an index of openness to foreign direct investment developed by the OECD. ${ }^{14}$ This index takes values between zero and unity and records restrictions on inward FDI by country and services sector in 2003 and 2006. Since the FDI restrictiveness index does not distinguish between source countries of investments, the country and sector-specific GL and MIIT indices for trade with the rest of the world were used. Finally, due to the limited number of observations, the regressions were run on pooled data using sector dummies. The results are presented in Table 4.

It is first noted that plastics and rubber (HS 39) and electronics (HS 85) have significantly higher predicted intra-industry trade than pharmaceuticals (HS 30) which is the omitted sector dummy in the regressions. However, intra-industry trade increases faster over time in pharmaceuticals than in textiles (HS 61 and 62) and motor vehicles (HS 87), but slower than in plastics and rubber (HS 39).

The FDI restrictiveness index is not logged in the regressions. Thus, the parameters reflect the percentage point change in the GL and MIIT indices respectively from a

\footnotetext{
${ }^{14}$ See Koyama and Golub (2006) for further details.
} 
Table 4. Regression results, intra-industry trade and FDI restrictions.

\begin{tabular}{ccccc}
\hline Left hand side variable & \multicolumn{2}{c}{ GL index } & \multicolumn{2}{c}{ MIIT index } \\
\hline $\begin{array}{c}\text { FDI restrictiveness } \\
\text { index }\end{array}$ & Total services & Business services & Total services & Business services \\
\hline \multirow{2}{*}{ ln GDP per capita } & $0.110^{*}$ & $0.145^{* * *}$ & 0.049 & $0.133^{* *}$ \\
& $(0.059)$ & $(0.058)$ & $(0.064)$ & $(0.064)$ \\
FDI restrictiveness & $-3.017^{* * *}$ & $-1.480^{* * *}$ & $-3.392^{* * *}$ & $-0.945^{* *}$ \\
& $(0.585)$ & $(0.426)$ & $(0.649)$ & $(0.453)$ \\
HS 39 dummy & $0.661^{* * *}$ & $0.653^{* * *}$ & $0.461^{* * *}$ & $0.451^{* * *}$ \\
& $(0.160)$ & $(0.157)$ & $(0.185)$ & $(0.182)$ \\
HS 61 dummy & -0.229 & -0.266 & $-0.449^{* *}$ & $-0.440^{* *}$ \\
& $(0.172)$ & $(0.170)$ & $(0.194)$ & $(0.197)$ \\
HS 62 dummy & -0.209 & -0.207 & $-0.465^{* *}$ & $-0.456^{* *}$ \\
& $(0.169)$ & $(0.169)$ & $(0.202)$ & $(0.202)$ \\
HS 85 dummy & $0.693^{* * *}$ & $0.684^{* * *}$ & 0.243 & 0.238 \\
& $(0.177)$ & $(0.174)$ & $(0.192)$ & $(0.189)$ \\
HS 87 dummy & 0.195 & 0.192 & $-0.498^{* *}$ & $-0.488^{* *}$ \\
& $(0.186)$ & $(0.181)$ & $(0.205)$ & $(0.201)$ \\
\hline $\mathrm{N}$ & 528 & 528 & 522 & 522 \\
AIC & 1.026 & 1.038 & 1.088 & 1.110 \\
BIC & -3064 & -3058 & -2942 & -2931 \\
\hline
\end{tabular}

Note: Standard errors are in parenthesis. ${ }^{*},{ }^{*}$, and ${ }^{* *}$ signify statistical significance at a 10,5 and $1 \%$ level respectively.

percentage point change in the FDI restrictiveness index at the mean. We see that a one percentage point increase in the overall services FDI restrictiveness index at the mean reduces the GL index by about three percentage points.

It is worth stressing that although the regression results provide evidence of a robust correlation between services trade costs and intra-industry trade in selected manufacturing industries, this does not imply causality. ${ }^{15}$ The relatively weak coverage of services trade data at the sector level, particularly for computer services, also suggests that results should be interpreted with caution. Nevertheless, the results are interesting, quite intuitive and could inspire further research into this important and somewhat under-researched area.

\footnotetext{
${ }^{15}$ Robustness checks have been conducted using different specifications of the regression equation, including taking logs of the GL, MIIT and trade cost indices and using trade costs measures estimated from different gravity regression techniques. The parameter values do vary somewhat with the estimation techniques, but the sign, level of significance and the order of magnitude of the parameter values are robust to methodology.
} 


\section{Summary and Conclusions}

This paper has analyzed possible relations between trade costs in business services and performance in downstream industries. It has demonstrated that services trade costs are significant even for presumably highly tradable services such as computer services. Trade costs and foreign direct investment restrictions have a relatively large impact on the performance of downstream manufacturing sectors. In particular, it appears that high trade costs and barriers to foreign direct investment in business services are strongly and negatively associated with the ability to engage in product differentiation as measured by the static and dynamic intra-industry trade index. Product differentiation in turn typically goes together with higher value added.

The role of business services for competitive markets in other sectors does not feature prominently in the trade and industrial policy debate. Trade policy tends to focus on market access for a country's exports, whereas industrial policy tends to focus on manufacturing. The findings of this study suggest that policy makers need to take a broader perspective. First it would be useful to investigate what are the sources of trade costs in business services. Given that many of these services are non-routine and interactive, occasional face-to-face communications may be required, often at short notice. A possible source of trade costs may thus be restrictions on movement of people, including long delays in obtaining a business visa. Other possible sources of trade costs are domestic regulations that set standards and qualification requirements. Even when perfectly legitimate, these may impose substantial compliance costs on foreign suppliers because of implementation procedures and large differences in the architecture of regulation. Finally, trade in business services involving small and poor countries is particularly sensitive to trade costs. Therefore, rather than assuming that these countries need extra protection for their services sectors, the opposite seems to be true. For these countries, it would also help if trading partners reduced the administrative burden on entrants. Compliance costs with regulation are an irritant for large multinational firm, but an insurmountable obstacle to medium sized firms from developing countries. More research is needed in order to explore the relation between such regulation - both its level and heterogeneity - and trade costs in services. 


\section{Acknowledgements}

The author would like to thank Douglas Lippoldt, participants at the GTAP conference in Penang Malaysia June 2010, colleagues in the OECD Trade and Agriculture Directorate and Members of the Working Party to the Trade Committee and an anonymous referee for useful comments and suggestions. The usual disclaimer applies.

Received 6 March 2011, Revised 21 March 2011, Accepted 4 April 2011

\section{References}

Ando, M. (2006), Fragmentation and Vertical Intra-Industry Trade in East Asia, The North American Journal of Economics and Finance, 17, 257-81.

Brülhart, M. (1994), Marginal Intra-Industry Trade: Measurement and Relevance for the Pattern of Industrial Adjustment, Weltwirtschaftliches Archiv, 130, 600-613.

Bryson. J. R. Daniels. P. W. Warf, B. (2004), Service Worlds; People, Organisations, Technologies. London: Routledge.

Diaz Fuentes, D. (1999), On the Limits of Post-Industrial Society: Structural Change and Services Sector Employment in Spain, Review of Applied Economic, 13, 111-23.

Egger, P. (2008), On the Role of Distance for Bilateral Trade, The World Economy, 31, 653-62. Francois, J. F. (1990), Trade in Producer Services and Returns due to Specialization under Monopolistic Competition, Canadian Journal of Economics, 23, 109-24.

Francois, J. F. and Woerz, J. (2008), Producer Services, Manufacturing Linkages, and Trade, Journal of Industry Competition and Trade, 8, 199-229

Gereffi, G. (1999), International Trade and Industrial Upgrading in the Apparel Commodity Chain, Journal of International Economics, 48, 37-70.

Grimes, S. (2006), Ireland's Emergence as a Centre for Internationally Traded Services", Regional Studies, 40, 1041-54.

Grubel, H. G. and Lloyd, P. J. (1975), Intra-Industry Trade: The Theory and Measurement of International Trade in Differentiated Products, New York: Wiley

Guerrieri, P. and Meliciani, V. (2005), Technology and International Competitiveness: the Interdependence between Manufacturing and Producer Services, Structural Change and Economic Dynamics, 16, 489-502.

Hanson, G. H., Mataloni, R. J. Jr. and Slaughter, M. J. (2005), Vertical Production Networks in Multinational Firms, The Review of Economics and Statistics, 87, 664-78

Kox, H. and Nordås, H. K. (2009), Quantifying Regulatory Barriers to Services Trade, OECD Trade Policy Working Paper 85.

Koyama, T. and Golub S. (2006), OECD's FDI Regulatory Restrictiveness Index: Revision and Extension to More Economies, OECD Economics Department Working Paper 525. 
Krugman, P. (1979), Increasing Returns, Monopolistic Competition and International Trade, Journal of International Economics, 9, 469-79.

Markusen, J. R. (1989), Trade in Producer Services and in other Specialized Intermediate Inputs, The American Economic Review, 79, 85-95.

Markusen, J: R. Rutherford, T. R. and Tarr, D. (2005), Trade and Direct Investment in Producer Services and the Domestic Market for Expertise, Canadian Journal of Economics, 38, 758-77.

Nordås, H. K., Geloso-Grosso, M. Pinali, E. (2006), Logistics and Time as a Trade Barrier, OECD Trade Policy Working Paper 35.

Nordås, H. K. (2010), Trade in Goods and Services: two Sides of the Same Coin? Economic Modelling. 27, 496-506.

Papke, L.E. and Wooldridge, J. M. (1996), Econometric Methods for Fractional Response Variables with an Application to 401(K) Plan Participation Rates. Journal of Applied Econometrics, 11, 619-32.

Robert-Nicoud, F. (2008), Offshoring of Routine Tasks and (de)Industrialisation: Threat or Opportunity-and for Whom? Journal of Urban Economics, 63, 517-35,

Santos Silva, J. M. C. and Tenreyro, S. (2006), The Log of Gravity. Review of Economics and Statistics, 88, 641-58.

Santos Silva, J. M.C. and Tenreyro, S. (2010), On the Existence of the Maximum Likelihood Estimates in Poisson Regression. Economic Letters, 107, 310-12. 